\title{
Annual organic matter dynamics in a small temperate mountain stream
}

\author{
Verónica Ferreira*, Ana Virgínia Lírio, João Rosa ${ }^{\dagger}$ and Cristina Canhoto \\ IMAR-CMA, Department of Life Sciences, University of Coimbra, P.O. box 3046, 3001-401 Coimbra, Portugal
}

Received 7 December 2012; Accepted 31 January 2013

\begin{abstract}
Temperate streams flowing through deciduous forests derive most of their energy and carbon from allochthonous organic matter supplied by the riparian vegetation mostly during the autumnal litter fall. The decomposition of this coarse particulate organic matter (CPOM) supports the aquatic foodwebs throughout the year. During the decomposition process, part of the CPOM is converted into fine particulate organic matter (FPOM). In this study, we assessed the relationships among decomposition rates of a dominant litter species, oak leaf litter (estimated by the litter bag approach in the presence and absence of macroinvertebrates), benthic CPOM stock and FPOM flux over 12 months in a temperate mountain oligotrophic stream. We also assessed the relationship between these organic matter variables and environmental variables over the same period. As expected from the seasonality in temperature, litter decomposition rates varied over the year and were positively correlated with water temperature and dissolved phosphorus concentration. However, benthic CPOM stock did not significantly change over the year; the higher rainfall in winter and the higher litter decomposition in spring might have compensated for each other in keeping the CPOM stock fairly constant year round. FPOM flux was positively correlated with litter decomposition rates as expected, and this relationship was primarily driven by the activities of detritivores and not of microbes. We can anticipate changes in the carbon cycle, both locally and downstream, if oligotrophic montane streams are subjected to temperature increases (e.g., due to removal of riparian vegetation or in a global warming scenario) and nutrient enrichment from effluents or agricultural activities.
\end{abstract}

Key words: Coarse particulate organic matter (CPOM) / fine particulate organic matter (FPOM) / leaf litter decomposition / nutrient availability / temperature

\section{Introduction}

In temperate regions, small forest streams constitute the majority of streams in a hydrological basin (Allan and Castillo, 2007). These streams are generally shaded by the riparian vegetation, which limits autochthonous primary production, but simultaneously provides the aquatic foodwebs with an alternative food source. The litter provided by the terrestrial vegetation, mostly in the form of leaves (Molinero and Pozo, 2004), is the main source of energy, carbon and nutrients for aquatic organisms (Vannote et al., 1980). The decomposition of this litter is therefore the basic ecosystem process in small shaded streams. The major litter input in temperate streams occurs during autumn/winter (Abelho and Graça, 1996; Molinero and Pozo, 2004; Richardson et al., 2009),

\footnotetext{
*Corresponding author: veronica@ci.uc.pt
}

$\dagger$ Present address: CFE - Centre for Functional Ecology, Department of Life Sciences, University of Coimbra, P.O. box 3046, 3001-401 Coimbra, Portugal and the decomposition of this organic matter generally supports aquatic foodwebs throughout the year. Once in water, litter is leached from soluble compounds, which results in the loss of up to $42 \%$ of initial litter mass to dissolved organic matter (Abelho, 2001). After the leaching, and the release of secondary compounds (e.g., phenolics), the coarse particulate organic matter (CPOM) remaining in the benthos is degraded by the activities of aquatic microbes, primarily aquatic hyphomycetes, and invertebrates, primarily detritivores (Hieber and Gessner, 2002; Cornut et al., 2010). These organisms convert dead organic matter into biomass that is then transferred to higher trophic levels, and simultaneously mineralize organic carbon into $\mathrm{CO}_{2}$ and release large amounts of fine particulate organic matter (FPOM) that is used by collectors locally and further downstream (Bärlocher and Brendelberger, 2004; Jonsson and Malmqvist, 2005; Cornut et al., 2010).

As an integrative process, litter decomposition is sensitive to changes in environmental conditions that 
affect fungal and detritivore communities and activities. Moderate increases in temperature and nutrient availability, for instance, have been shown to stimulate fungal and detritivore activities, which translates into accelerated litter decomposition (Rosemond et al., 2002; Ferreira et al., 2006b; Gulis et al., 2006). Litter decomposition rates partially determine the CPOM standing stock and the FPOM flux: for instance, faster decomposition rates can lead to decreases in the CPOM stock in the benthos and to increases in the amount of FPOM transported downstream (Cuffney et al., 1990). Forest type and stream hydromorphology can also modulate the amount of benthic CPOM and FPOM flux (Cuffney and Wallace, 1989; Larrañaga et al., 2003; Molinero and Pozo, 2004; Richardson et al., 2009).

Here, we assess the relationships among decomposition rates of oak leaf litter, benthic CPOM stock and FPOM flux over 12 months in a temperate mountain oligotrophic stream. We also assessed the relationship between these organic matter variables and environmental variables over the same period. Temperate streams flowing through deciduous forests receive most of the annual litter input during the autumnal litter fall, which establishes the maximum possible CPOM standing stock. Discharge and retentive structures act directly, while water physicchemical variables (e.g., temperature, nutrient concentration) act indirectly, through its effects on the biota and litter decomposition rates, determining the CPOM stock in the benthos and the FPOM flux throughout the year. Since in temperate regions there is seasonality in temperature and rainfall, we hypothesize that litter decomposition rates, benthic CPOM stock and FPOM flux will vary over the year. Litter decomposition is expected to be positively correlated with water temperature and FPOM flux, while negatively correlated to benthic CPOM stock. The understanding of the relationship between organic matter variables and environmental variables in pristine or nearly pristine streams is necessary to allow predictions on the response of organic matter dynamics in the face of anthropogenic pressures.

\section{Methods}

\section{Study site}

This study was performed in a branch of a second-order mountain stream in Central Portugal (Ribeira do Candal, Lousã Mountain; 40 $4^{\prime} 44^{\prime \prime} \mathrm{N}, 8^{\circ} 12^{\prime} 10^{\prime \prime} \mathrm{W}, 620 \mathrm{~m}$ asl). This nearly pristine stream drains an area of $0.8 \mathrm{~km}^{2}$ covered by mixed deciduous forest dominated by chestnut (Castanea sativa Mill.) and oak (Quercus robur $\mathrm{L}$.). The study reach is approximately $20 \mathrm{~m}$ long, $0.5 \mathrm{~m}$ wide and $10 \mathrm{~cm}$ deep, and ends in a small waterfall. The bedrock is schistose and the stream reach substrate is composed mainly of cobles, pebbles and sand. The stream usually flows year round, but may dry in hot and dry summers, which has occurred more frequently in the last few years.

\section{Rainfall and water variables}

From November 2010 to February 2012, rainfall was determined at approximately weekly intervals at the stream site by using two pluviometers, each displaced on each side of the stream, which allowed the collection of rain water in a known area $(15 \mathrm{~cm}$ diameter). The water retained in the two pluviometers was averaged. Results were expressed as total rainfall per month $(\mathrm{mm})$.

During the same period, water temperature was recorded hourly using a submerged data logger (Hobo Pendant, Onset Computer Corp., Massachusetts, USA). Hourly temperature records were averaged to produce daily means and results were expressed as mean monthly temperature $\left({ }^{\circ} \mathrm{C}\right.$ ). Electrical conductivity (LF 330, WTW, Weilheim, Germany), pH (pH 3110, WTW) and oxygen saturation (Oxi 3210, WTW) were recorded at approximately weekly intervals using field probes. Discharge was determined by the volumetric method at the beginning of the stream reach by recording the time needed to fill a $10-\mathrm{L}$ bucket. At the same time $300 \mathrm{~mL}$ of stream water were collected, filtered through glass fiber filters $(47 \mathrm{~mm}$ diameter, $0.7 \mu \mathrm{m}$ pore size; Millipore APFF04700, Millipore, Massachusetts, USA), transported in a cooler to the laboratory, and frozen until analyzed for nutrient concentrations. Nitrate concentration was determined by ionic chromatography (Dionex DX-120, Sunnyvale, CA, USA), and soluble reactive phosphorus (SRP) concentration was determined by the ascorbic acid method (APHA, 1995). Alkalinity was determined by titration of $50-100$ $\mathrm{mL}$ of stream water with $\mathrm{H}_{2} \mathrm{SO}_{4} 0.02 \mathrm{~N}$ to an endpoint of pH 4.2 (APHA, 1995). Results were expressed as mean daily values for each month. Environmental variables were not determined in July-October 2011 because the stream reach was dry.

\section{Leaf litter decomposition}

Oak (Q. robur) leaves were collected just after abscission in Cioga do Campo, Central Portugal, in autumn 2008, air-dried at room temperature and stored in the dark until needed. Monthly, from late October 2010 to late January 2012, leaves (2.25-2.58 g) were enclosed in coarsemesh bags $(\mathrm{CM} ; 10 \times 12 \mathrm{~cm}, 10 \mathrm{~mm}$ mesh) and in finemesh bags (FM; $10 \times 12 \mathrm{~cm}, 0.5 \mathrm{~mm}$ mesh) to include or to exclude macroinvertebrates, respectively. Six litter bags of each mesh size were deployed at the end of each month in the stream reach and leaves allowed to decompose for 30 days. Litter decomposition was not determined in JulyOctober 2011 because the stream reach was dry. Upon collection, litter bags were placed individually in zip-loc bags, transported to the laboratory in a cooler and promptly processed. In the laboratory, leaves were rinsed with tap water over a $0.5 \mathrm{~mm}$ mesh sieve to recover small leaf fragments. Remaining litter was oven-dried $\left(105^{\circ} \mathrm{C}\right.$, $48 \mathrm{~h})$, weighed $( \pm 0.1 \mathrm{mg})$, ignited $\left(550^{\circ} \mathrm{C}, 4 \mathrm{~h}\right)$ and reweighed to allow determination of ash-free dry mass (AFDM) remaining. On day 0 , three extra litter bags for 
each mesh type were taken to the field, submerged for approximately $10 \mathrm{~min}$, returned to the laboratory and treated as above to allow determination of initial AFDM. The fraction of AFDM remaining (AFDM remaining/ initial AFDM) in each month was Ln-transformed and used to compute the litter decomposition rate assuming an exponential decay over 30 days, and results were expressed as decomposition rate $(k)$ per day.

\section{CPOM in the benthos}

CPOM in the benthos was sampled with perforated plastic trays $(21 \times 13 \times 6 \mathrm{~cm})$ that were filled with clean stream sediment and incubated in the stream. Monthly, from October 2010 to January 2012, three trays were placed along the stream reach and retrieved after 30 days of incubation. CPOM stock was not determined in JulyOctober 2011 because the stream reach was dry. The trays were bagged individually and transported to the laboratory in a cooler. The content of the trays was rinsed with tap water over a $0.5 \mathrm{~mm}$ mesh sieve, and CPOM ( $>0.5$ $\mathrm{mm})$ was sorted. CPOM was oven-dried $\left(105^{\circ} \mathrm{C}, 48 \mathrm{~h}\right)$, weighed $( \pm 0.1 \mathrm{mg})$, ignited $\left(550^{\circ} \mathrm{C}, 4 \mathrm{~h}\right)$ and reweighed to allow determination of AFDM. Results were expressed as g AFDM per $\mathrm{m}^{2}$.

\section{FPOM in suspension}

FPOM in suspension was sampled once each month, on the same day as benthic CPOM and litter bags collection. Monthly, from November 2010 to February 2012, three 5-L plastic bottles were filled with stream water at the end of the study reach; care was taken to avoid disturbing the sediment before and during water collection. FPOM in suspension was not determined in July-October 2011 because the stream reach was dry. The bottles were promptly transported to the laboratory, the water was filtered through ignited glass fiber filters $(47 \mathrm{~mm}$ diameter, $0.7 \mu \mathrm{m}$ pore size; Millipore APFF04700, Millipore) and the filters were stored at $-20{ }^{\circ} \mathrm{C}$ until processed. Filters were lyophilized over night, weighed $( \pm 0.1 \mathrm{mg})$, ignited $\left(550^{\circ} \mathrm{C}\right.$, $4 \mathrm{~h}$ ) and reweighed to allow determination of AFDM. FPOM flux in mg AFDM per second was determined by multiplying FPOM mass in $1 \mathrm{~L}$ of stream water with discharge.

\section{Data analyses}

Litter decomposition rate, CPOM stock and FPOM flux were compared among months by Krushall-Wallis test since this is the safest way to analyze data based on small sample sizes. Leaf litter decomposition was compared between coarse and fine mesh bags for each month (fraction AFDM remaining, $N=6$ ) by $t$-tests, and across months $\left(k \cdot \mathrm{d}^{-1}, N=12\right)$ by paired $t$-test. Significant differences were set at $P \leq 0.050$. Relationships between organic matter variables and water variables were assessed by
Table 1. Monthly rainfall and water variables (mean \pm SE) in a small mountain stream in Central Portugal from November 2010 to February 2012. There was no rainfall between July and October 2011 and the stream was dry during this period.

\begin{tabular}{lc}
\hline Environmental variables & Mean $\pm \mathrm{SE}$ \\
\hline Rainfall $(\mathrm{mm})$ & $113.0 \pm 28.7$ \\
Water temperature $\left({ }^{\circ} \mathrm{C}\right)$ & $9.3 \pm 0.6$ \\
Electrical conductivity $\left(\mu \mathrm{S} . \mathrm{cm}^{-1}\right)$ & $26.4 \pm 0.3$ \\
$\mathrm{O}_{2}$ saturation $(\%)$ & $89.0 \pm 3.6$ \\
$\mathrm{pH}$ & $7.3 \pm 0.1$ \\
$\mathrm{Alkalinity}\left(\mathrm{mg} \mathrm{CaCO} \mathrm{Ca}_{3} . \mathrm{L}^{-1}\right)$ & $5.3 \pm 0.4$ \\
$\mathrm{NO}_{3}-\mathrm{N}\left(\mu \mathrm{g} . \mathrm{L}^{-1}\right)$ & $61.6 \pm 10.1$ \\
$\mathrm{SRP}\left(\mu \mathrm{g} . \mathrm{L}^{-1}\right)$ & $11.1 \pm 4.0$ \\
\hline
\end{tabular}

Pearson correlation as we anticipated them to be linear; significant correlations were set at $P \leq 0.050$. All analyses were performed with Statistica 7 software (StatSoft Inc., Tulsa, Oklahoma, USA).

\section{Results}

\section{Rainfall and water variables}

The study reach was located in a temperate region. As expected, the maximum rainfall occurred during the winter months (November-February), although the winter was drier in 2011/12 than in 2010/11. No rainfall was registered during the summer months. Water temperature also presented seasonality with lower temperature during November-March and increases from April.

During the study period (November 2010-February 2012), the stream was circumneutral $(7.3 \pm 0.1 \mathrm{pH}$ units, mean $\pm \mathrm{SE})$, softwater $\left(5.3 \pm 0.4 \mathrm{mg} \mathrm{Ca} \overline{\mathrm{C}} \mathrm{O}_{3} \cdot \mathrm{L}^{-1}\right)$, well oxygenated ( $91.0 \pm 3.6 \% \mathrm{O}_{2}$ saturation) and oligotrophic $\left(61.6 \pm 10.1 \mu \mathrm{g} \mathrm{NO}_{3}-\mathrm{N}^{-L^{-1}} ; 11.1 \pm 4.0 \mu \mathrm{g} \mathrm{SRP.L}{ }^{-1}\right)$ (Table 1).

\section{Organic matter variables}

Litter decomposition rate varied between 0.0056 and $0.0421 . \mathrm{d}^{-1}$ in coarse mesh bags and between 0.0053 and 0.0104. $\mathrm{d}^{-1}$ in fine mesh bags (Fig. 1). Litter decomposition in coarse mesh bags was significantly faster in MarchJune 2011 than in January 2012 (Kruskal-Wallis, $P<0.019)$, faster in March, May and June 2011 than in February $2012(P<0.032)$, faster in May and June 2011 than in December $2010(P<0.025)$ and faster in June 2011 than in December $2011(P=0.030)$. Similarly, microbialinduced litter decomposition determined in fine mesh bags was significantly faster in May, June and November 2011 than in January 2012 (Kruskal-Wallis, $P<0.020$ ) and faster in June 2011 than in December $2011(P=0.004)$ (Fig. 1).

Mean monthly CPOM stock in the benthos ranged between 11 and 176 g AFDM.m ${ }^{-2}$ (Fig. 2). However, CPOM stock did not statistically differ among months (Kruskal-Wallis, $P>0.598$ ), which can be attributed to 


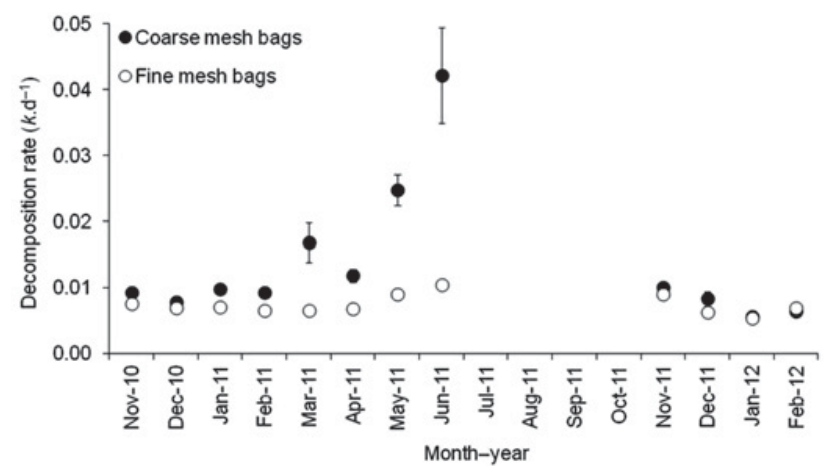

Fig. 1. Decomposition rates of oak leaf litter enclosed in coarse and fine mesh bags incubated monthly in a small mountain stream in Central Portugal. Values are monthly means \pm SE.

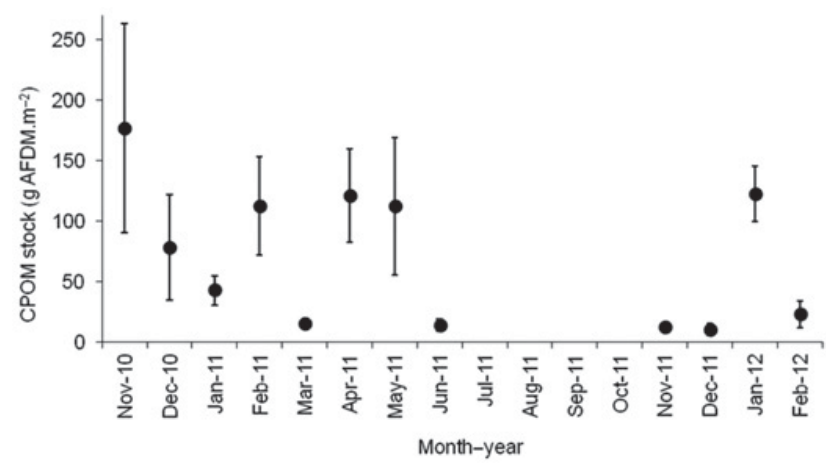

Fig. 2. CPOM stock in the benthos in a small mountain stream in Central Portugal. Values are monthly means \pm SE.

high variability among sampling locations within the stream.

FPOM flux varied between 0.9 and $3.8 \mathrm{mg} \mathrm{AFDM.s}{ }^{-1}$. FPOM flux was significantly higher in March and May 2011 than in December 2010 (Kruskal-Wallis, $P=0.043$ and 0.013 , respectively) and higher in May 2011 than in February 2012 ( $P=0.049)$ (Fig. 3).

\section{Relationships between organic matter variables and water variables}

Decomposition rates in fine mesh bags and FPOM flux were positively correlated with decomposition rates in coarse mesh bags (Pearson correlation, $r=0.80, P=0.002$ and $r=0.59, P=0.043$, respectively). No relationship was found between CPOM stock and any other organic matter variable (Pearson correlation, $r<-0.34, P>0.280$ ), nor between FPOM flux and decomposition rates in fine mesh bags $(r=0.29, P=0.361)$ (Table 2). Litter decomposition in both mesh bags was positively correlated with water temperature (Pearson correlation, $r=0.77$ in $\mathrm{CM}$ and 0.74 in FM, $P<0.006)$ and SRP concentration $(r=0.91$ in $\mathrm{CM}$ and 0.74 in FM, $P<0.006$ ) (Table 2). Litter decomposition in coarse mesh bags was also positively correlated with electrical conductivity (Pearson correlation, $r=0.71$, $P=0.010)$ and negatively correlated with nitrogen concentration $(r=-0.70, P=0.011)$ (Table 2). It should

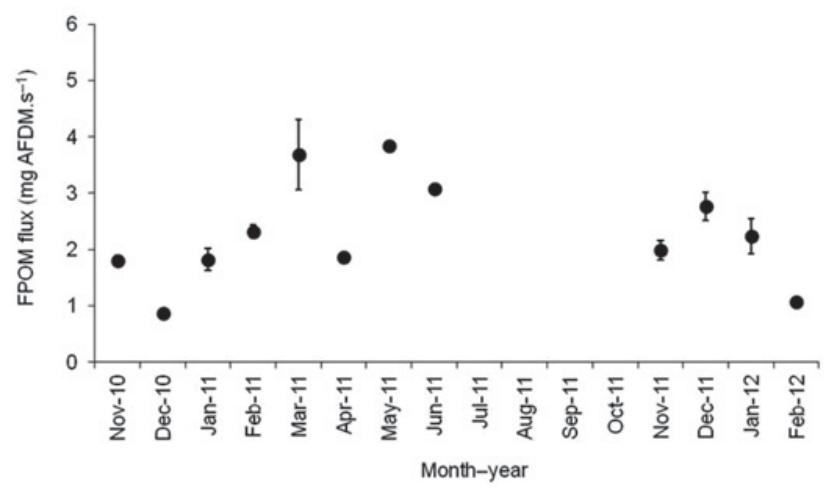

Fig. 3. FPOM flux in a small mountain stream in Central Portugal. Values are means of daily values for each month $( \pm \mathrm{SE})$.

be noted that nitrogen and SRP concentration were negatively correlated (Pearson correlation, $r=-0.81$, $P=0.001)$, while SRP and water temperature were positively correlated $(r=0.76, P=0.004)$. CPOM stock was not significantly correlated with any water variable (Pearson correlation, $|r|<0.29, P>0.361$ ), while FPOM flux was negatively correlated with $\mathrm{pH}(r=-0.67$, $P=0.017$ ) (Table 2).

\section{Discussion}

Decomposition of oak leaf litter varied seasonally, with faster litter mass loss in spring than in autumn and winter. This seasonality in litter decomposition can be explained by increases in water temperature and SRP concentration in April-June, as suggested by the positive correlation between decomposition rates and these water variables. Previous studies have also shown faster litter decomposition rates in warmer than in colder seasons (Chergui and Pattee, 1990; Swan and Palmer, 2004; Nikolcheva and Bärlocher, 2005; Ferreira et al., 2006a) and also when nutrient availability increases (Rosemond et al., 2002; Gulis et al., 2006). The simultaneous increase of both water variables, as in our study, was shown to have synergistic effects on litter decomposition in a laboratory study (Ferreira and Chauvet, 2011). The stimulatory effect of increases in temperature and nutrients on litter decomposition is most likely mediated by enhanced microbial and detritivore activities. Increases in temperature in the range observed in this study $\left(5.5-12.8^{\circ} \mathrm{C}\right)$ have been shown to stimulate fungal growth and reproductive activity that results in the conversion of litter carbon into fungal carbon with the consequent decrease in litter mass (Dang et al. 2009; Ferreira and Chauvet, 2011). Also, the study reach was oligotrophic, which means that the microbial activity was probably nutrient limited (also note that oak litter is nutrient poor; Gulis et al., 2006) and therefore highly sensitive to even small increases in nutrient availability. Increases in SRP concentration in the range observed in this study $\left(1.3-44.2 \mu \mathrm{g} . \mathrm{L}^{-1}\right)$ stimulated fungal and bacterial activities and litter decomposition in previous studies (Rosemond et al., 2002; Gulis and 
Table 2. Pearson correlation among organic matter variables and selected water variables. $r$ values are given; bold values denote significant correlations $(P \leq 0.050)$.

\begin{tabular}{|c|c|c|c|c|}
\hline \multirow[b]{2}{*}{ Organic matter and water variables } & \multicolumn{2}{|c|}{ Litter decomposition } & \multirow{2}{*}{$\begin{array}{c}\text { CPOM stock } \\
\left(\text { g AFDM.m }^{-2}\right)\end{array}$} & \multirow{2}{*}{$\begin{array}{c}\text { FPOM flux } \\
\text { (mg AFDM.s }{ }^{-1}\end{array}$} \\
\hline & in $\mathrm{CM}\left(k \cdot \mathrm{d}^{-1}\right)$ & in $\mathrm{FM}\left(k \cdot \mathrm{d}^{-1}\right)$ & & \\
\hline Litter decomposition in CM $\left(k \cdot \mathrm{d}^{-1}\right)$ & 1.00 & & & \\
\hline Litter decomposition in FM $\left(k \cdot \mathrm{d}^{-1}\right)$ & 0.80 & 1.00 & & \\
\hline CPOM stock (g AFDM.m ${ }^{-2}$ ) & -0.22 & -0.34 & 1.00 & \\
\hline FPOM flux (mg AFDM.s ${ }^{-1}$ ) & 0.59 & 0.29 & -0.08 & 1.00 \\
\hline Temperature $\left({ }^{\circ} \mathrm{C}\right)$ & 0.77 & 0.74 & 0.01 & 0.56 \\
\hline Discharge $\left(\mathrm{L} . \mathrm{s}^{-1}\right)$ & -0.03 & -0.01 & -0.17 & -0.14 \\
\hline Electrical conductivity $\left(\mu \mathrm{S} . \mathrm{cm}^{-1}\right)$ & 0.71 & 0.46 & 0.20 & 0.27 \\
\hline $\mathrm{O}_{2}$ saturation $(\%)$ & 0.29 & 0.13 & -0.06 & 0.08 \\
\hline $\mathrm{pH}$ & -0.50 & -0.31 & 0.03 & -0.67 \\
\hline Alkalinity $\left(\mathrm{mg} \mathrm{CaCO} 3 \cdot \mathrm{L}^{-1}\right)$ & -0.46 & -0.32 & -0.29 & -0.33 \\
\hline $\mathrm{NO}_{3}-\mathrm{N}\left(\mu \mathrm{g} . \mathrm{L}^{-1}\right)$ & -0.70 & -0.50 & -0.17 & -0.31 \\
\hline $\operatorname{SRP}\left(\mu \mathrm{g} . \mathrm{L}^{-1}\right)$ & 0.91 & 0.74 & 0.04 & 0.34 \\
\hline
\end{tabular}

CM, coarse mesh; FM, fine mesh; CPOM, coarse particulate organic matter; AFDM, ash-free dry mass; FPOM, fine particulate organic matter; SRP, soluble reactive phosphorus.

Suberkropp, 2003; Gulis et al., 2006). Detritivore growth and feeding activities are also stimulated by increases in temperature within the range observed here (González and Graça, 2003; Azevedo-Pereira et al., 2006). However, detritivores prefer litter already colonized by fungi since it is softer, has higher nutrient concentration and is enriched with exoenzymes that aid the invertebrates in the degradation of complex polysaccharides (Graça et al., 2001; Canhoto and Graça, 2008; Chung and Suberkropp, 2009). The general dependence of detritivores on fungi explains the positive correlation between microbial-induced and overall litter decomposition.

The correlation between litter decomposition and dissolved phosphorus can, however, have an alternative interpretation: the dynamics of dissolved nutrient concentrations over the year can be a result of the annual dynamics of litter fall and decomposition. During seasons of high biological activity, nutrient immobilization might lead to decreases in the concentration of dissolved nutrients (Mulholland, 2004; Webster et al., 2009). In the study stream, high biological activity occurs most likely during autumn/winter, when litter input is maximal (Abelho and Graça, 1996; Molinero and Pozo, 2004; Richardson et al., 2009) and litter is colonized by microbes and invertebrates (Hieber and Gessner, 2002; Cornut et al., 2010), and early spring, when primary production is enhanced by the increase in temperature and irradiation as the canopy still did not close (Izagirre and Elosegi, 2005). These changes in biological activity over the year might explain the lower SRP concentration during November-March. The effect of nutrients mineralization on dissolved nutrient concentration is more scarce (Webster et al., 2009).

The seasonality in overall litter decomposition (in coarse mesh bags) might also be correlated with detritivore phenology. In temperate regions, most invertebrate detritivores are insects from the orders Plecoptera and Trichoptera (Boyero et al., 2011), which have their life cycles synchronized with the autumnal litter fall so that early instars take advantage of the organic matter that enters the streams in autumn/winter. The decomposing litter supplies detritivores until spring/early summer, when the individuals are ready to emerge as winged adults (Cummins et al., 1989). The faster litter decomposition in coarse mesh bags in March-June might be partially due to the activities of late and large instars of Capnidae, Leuctridae and Nemouridae plecoptera, Lepidostomatidade, Limnephilidae and Sericostomatidade trichoptera, and Tipulidae diptera, present in the study reach. In a nearby stream, González and Graça (2003) found the largest individuals of Sericostoma vittatum (Rambur) during spring months. Benstead and Huryn (2011) attributed the extreme seasonality of willow litter decomposition in an arctic stream primarily to detritivore phenology, while water temperature remained fairly constant over the year.

In our study, benthic CPOM stock did not significantly differ among months, which agrees with a previous report that found no seasonality in CPOM stock in streams flowing through deciduous forest, but high seasonality in streams flowing through eucalyptus forests in central Portugal (Abelho and Graça, 1996). However, Abelho and Graça (1998) in other streams and Molinero and Pozo (2004) found seasonality in benthic CPOM standing stock in streams flowing through deciduous forests, with higher CPOM stock in late autumn/winter. The annual dynamics of CPOM stock partially depends on the forest composition (Abelho and Graça, 1996; Molinero and Pozo, 2004). The phenology, quantity and quality of litter inputs, which vary with forest composition, determine the benthic CPOM standing stock over the year directly, and indirectly by influencing the sensitivity of submerged litter to transport downstream (e.g., Canhoto and Graça, 1998; Larrañaga et al., 2003) and to decomposition (e.g., high quality and soft litter decomposes faster than low quality and hard litter; Gessner and Chauvet, 1994). In our case, the absence of significant difference in CPOM standing stock over the year might be partially explained by chestnut and oak trees shedding leaves mostly during November-December and during January-February, 
respectively, chestnut leaves decomposing faster than oak leaves (Molinero et al., 1996; Ferreira et al., 2012), and chestnut fruits and cupules remaining in the stream for very long periods. The differences in CPOM stock among studies addressing similar forest streams might also be due to differences in stream characteristics as channel gradient, current velocity and the presence of retentive structures, which have been shown to affect litter retentiveness and consequently benthic organic matter stock (Larrañaga et al., 2003; Richardson et al., 2009). Although differences in stream characteristics might help explaining differences between our results and those of previous studies, they do not seem to contribute to explain the CPOM stock within our stream over the study period. Also, although litter decomposition was faster in the warmer months than during winter, this did not translate into a decrease in benthic CPOM standing stock during the warmer months. The absence of seasonality on CPOM stock might be explained by a positive correlation between rainfall and litter fall: higher rainfall in autumn and winter than in spring, which might have flushed litter downstream in the colder months compensating for the higher litter input during this period. We have to keep in mind, however, the high spatial variability as denoted by the large error bars associated with the monthly CPOM values.

FPOM flux tended to be higher in the warmer than in the colder months, which was expected as a result from accelerated litter decomposition in the warmer months. Invertebrate-induced litter fragmentation and feces production, litter maceration by microbes and conidial production by aquatic hyphomycetes lead to the production of large amounts of FPOM (Cummins and Klug, 1979; Gessner et al., 1999). The important role of invertebrates on FPOM production was demonstrated by Cuffney et al. (1990) by comparing the FPOM exported from a control stream and a stream treated with pesticide, before and after treatment started; annual FPOM export decreased drastically in the treated stream after pesticide addition when compared with the control stream or the pretreatment year, which was correlated with a decrease in litter decomposition (Cuffney et al., 1990). The increase in FPOM flux in the warmer months might also be attributed to increases in conidial production induced by warmer temperature; higher water temperature usually stimulates conidial production by leaf decomposition fungi (Nikolcheva and Bärlocher, 2005; Ferreira and Chauvet, 2011). Nevertheless, the fact that FPOM flux correlates with litter decomposition in coarse mesh bags but not in fine mesh bags suggests that invertebrate activity on decomposing litter is probably the main pathway for FPOM production in our stream. Soil organic particles or periphyton fragments might also contribute to FPOM in streams (Sakamaki and Richardson, 2011). However, this was probably not the case here since higher FPOM flux was found in months with low rainfall and consequently low transport of soil particles to the stream. Also, the study stream was shaded by the riparian trees during the months of higher FPOM flux, and therefore the instream primary production was probably low.
This study suggests that water temperature and dissolved nutrients (SRP in our case) are major environmental drivers of litter decomposition in temperate montane oligotrophic streams. In these streams, litter decomposition is most sensitive to simultaneous increases in temperature and nutrient availability through its stimulatory effect on microbial and invertebrate activities. Changes in the rate of litter decomposition affect the amount of FPOM that is transported downstream, which might impact foodwebs where collectors are important components (Bärlocher and Brendelberger, 2004; Jonsson and Malmqvist, 2005). Therefore, we can anticipate changes in the carbon cycle, both locally and downstream, if these streams are subject to temperature increases (e.g., due to removal of riparian vegetation or in a global warming scenario) and nutrient enrichment from effluents or agricultural activities.

Acknowledgements. This study was financed by the IMAR-CMA, the FEDER European Funds through the Program Operational Factors of Competitiveness (COMPETE) and National Funds through the Portuguese Science and Technology Foundation (FCT, project PTDC/CLI/67180/2006). Financial support granted by the FCT to VF (postdoctoral fellowships SFRH/BPD/34368/2006 and SFRH/BPD/76482/ 2011, program POPH/FSE) is also gratefully acknowledged.

\section{References}

Abelho M., 2001. From litterfall to breakdown in streams: a review. Scientific World, 1, 656-680.

Abelho M. and Graça M.A.S., 1996. Effects of eucalyptus afforestation on leaf litter dynamics and macroinvertebrate community structure of streams in Central Portugal. Hydrobiologia, 324, 195-204.

Abelho M. and Graça M.A.S., 1998. Litter in a first-order stream of a temperate deciduous forest (Margaraça forest, Central Portugal). Hydrobiologia, 386, 147-152.

Allan J.D. and Castillo M.M., 2007. Stream ecology. Structure and Function of Running Waters (2nd edn,), Springer, Dordrecht, The Netherlands, $436 \mathrm{p}$.

APHA, 1995. Standard Methods for the Examination of Water and Watershed (19th edn,), American Public Health Association, Washington, DC, USA.

Azevedo-Pereira H.V.S., Graça M.A.S. and González J.M., 2006. Life history of Lepidostoma hirtum in an Iberian stream and its role in organic matter processing. Hydrobiologia, 559, 183-192.

Bärlocher F. and Brendelberger H., 2004. Clearance of aquatic hyphomycete spores by a benthic suspension feeder. Limnol. Oceanogr., 49, 2292-2296.

Benstead J.P. and Huryn A.D., 2011. Extreme seasonality of litter breakdown in an arctic spring-fed stream is driven by shredder phenology, not temperature. Freshwat. Biol., 56, 2034-2044.

Boyero L., Pearson R.G., Dudgeon D., Graca M.A.S., Gessner M.O., Albarino R.J., Ferreira V., Yule C.M., Boulton A.J., Arunachalam M., Callisto M., Chauvet E., Ramirez A., Chara J., Moretti M.S., Goncalves J.F. Jr, Helson J.E., 
Chará-Serna A.M., Encalada A.C., Davies J.N., Lamothe S., Cornejo A., Li A.O.Y., Buria L.M., Villanueva V.D., Zuniga M.C. and Pringle C.M., 2011. Global distribution of a key trophic guild contrasts with common latitudinal diversity patterns. Ecology, 92, 1839-1848.

Canhoto C. and Graça M.A.S., 1998. Leaf retention: a comparative study between two stream categories and leaf types. Verh. Int. Verein. Limnol., 26, 990-993.

Canhoto C. and Graça M.A.S., 2008. Interactions between fungi (Aquatic Hyphomycetes) and invertebrates. In: Sridhar K.R., Bärlocher F. and Hyde K.D. (eds.), Novel Techniques and Ideas in Mycology. Fungal diversity research series, University of Hong Kong, Hong Kong, 205-325.

Chergui H. and Pattee E., 1990. The influence of season on the breakdown of submerged leaves. Archiv. Hydrobiol., 120, $1-12$.

Chung N. and Suberkropp K., 2009. Effects of aquatic fungi on feeding preferences and bioenergetics of Pycnopsyche gentilis (Trichoptera; Limnephilidae). Hydrobiologia, 630, 257-269.

Cornut J., Elger A., Lambrigot D., Marmonier P. and Chauvet E., 2010. Early stages of leaf decomposition are mediated by aquatic fungi in the hyporheic zone of woodland streams. Freshwat. Biol., 55, 2541-2556.

Cuffney T.F. and Wallace J.B., 1989. Discharge-export relationships in headwater streams: the influence of invertebrate manipulations and drought. J. N. Am. Benthol. Soc., 8, 331-341.

Cuffney T.F., Wallace J.B. and Lugthart G.J., 1990. Experimental evidence quantifying the role of benthic invertebrates in organic matter dynamics of headwater streams. Freshwat. Biol., 23, 281-299.

Cummins K.W. and Klug M.T., 1979. Feeding ecology of stream invertebrates. Annu. Rev. Ecol. Syst., 10, 147-172.

Cummins K.W., Wilzbach M.A., Gates D.M., Perry J.B. and Talaiferro W.B., 1989. Shredders and rinaprian vegetation. Bioscience, 39, 24-30.

Dang C.K., Schindler M., Chauvet E. and Gessner M.O., 2009. Temperature oscillation coupled with fungal community shifts can modulate warming effects on litter decomposition. Ecology, 90, 122-131.

Ferreira V. and Chauvet E., 2011. Synergistic effects of water temperature and dissolved nutrients on litter decomposition and associated fungi. Global Change Biol., 17, 551-564.

Ferreira V., Encalada A.C. and Graça M.A.S., 2012. Effects of litter diversity on decomposition and biological colonization of submerged litter in temperate and tropical streams. Freshwat. Sci., 31, 945-962.

Ferreira V., Graça M.A.S., de Lima J.L.M.P. and Gomes R., 2006a. Role of physical fragmentation and invertebrate activity in the breakdown rate of leaves. Arch. Hydrobiol., 165, 493-513.

Ferreira V., Gulis V. and Graça M.A.S., 2006b. Whole-stream nitrate addition affects litter decomposition and associated fungi but not invertebrates. Oecologia, 149, 718-729.

Gessner M.O. and Chauvet E., 1994. Importance of stream microfungi in controlling breakdown rates of leaf litter. Ecology, 75, 1807-1817.

Gessner M.O., Chauvet E. and Dobson M., 1999. A perspective on leaf litter breakdown in streams. Oikos, 85, 377-384.

González J.M. and Graça M.A.S., 2003. Conversion of leaf litter to secondary production by a shredding caddis-fly. Freshwat. Biol., 48, 1578-1592.
Graça M.A.S., Cressa C., Gessner M.O., Feio M.J., Callies K.A. and Barrios C., 2001. Food quality, feeding preferences, survival and growth of shredders from temperate and tropical streams. Freshwat. Biol., 46, 947-957.

Gulis V. and Suberkropp K., 2003. Leaf litter decomposition and microbial activity in nutrient-enriched and unaltered reaches of a headwater stream. Freshwat. Biol., 48, 123134.

Gulis V., Ferreira V. and Graça M.A.S., 2006. Stimulation of leaf litter decomposition and associated fungi and invertebrates by moderate eutrophication: implications for stream assessment. Freshwat. Biol., 51, 1655-1669.

Hieber M. and Gessner M.O., 2002. Contribution of stream detritivores, fungi, and bacteria to leaf breakdown based on biomass estimates. Ecology, 83, 1026-1038.

Izagirre O. and Elosegi A., 2005. Environmental control of seasonal and inter-annual variations of periphytic biomass in a North Iberian stream. Ann. Limnol. - Int. J. Lim., 41, 35-46.

Jonsson H. and Malmqvist B., 2005. Species richness and composition effects in a detrital processing chain. J. N. Am. Benthol. Soc., 24, 798-806.

Larrañaga S., Díez J.R., Elosegi A. and Pozo J., 2003. Leaf retention in streams of the Agüera basin (northern Spain). Aquat. Sci., 65, 158-166.

Molinero J. and Pozo J., 2004. Impact of a eucalyptus (Eucalyptus globulos Labill.) plantation on the nutrient content and dynamics of coarse particulate organic matter (CPOM) in a small stream. Hydrobiologia, 528, 143-165.

Molinero J., Pozo J. and González E., 1996. Litter breakdown in streams of the Agüera catchment: influence of dissolved nutrients and land use. Freshwat. Biol., 36, 745-756.

Mulholland P.J., 2004. The importance of in-stream uptake for regulating stream concentrations and outputs of $\mathrm{N}$ and $\mathrm{P}$ from a forested watershed: evidence from long-term chemistry records for Walker Branch Watershed. Biogiochemistry, 70, 403-426.

Nikolcheva J.G. and Bärlocher F., 2005. Seasonal and substrate preferences of fungi colonizing leaves in streams: traditional versus molecular evidence. Environ. Microbiol., 7, 270-280.

Richardson J.S., Hoover T.M. and Lecerf A., 2009. Coarse particulate organic matter dynamics in small streams: towards linking function to physical structure. Freshwat. Biol., 54, 2116-2126.

Rosemond A.D., Pringle C.M., Ramírez A., Paul M.J. and Meyer J.L., 2002. Landscape variation in phosphorus concentration and effects on detritus-based tropical streams. Limnol. Oceanogr., 47, 278-289.

Sakamaki T. and Richardson J.S., 2011. Biogeochemical properties of fine particulate organic matter as an indicator of local and catchment impacts on forested streams. J. Appl. Ecol., 48, 1462-1471.

Swan C.M. and Palmer M.A., 2004. Leaf diversity alters litter breakdown in a Piedmont stream. J. N. Am. Benthol. Soc., 23, 15-28.

Vannote R.L., Minshall G.W., Cummins K.W., Sedell J.R. and Cushing C.E., 1980. The river continuum concept. Can. J. Fish. Aquat. Sci., 37, 130-137.

Webster J.R., Newbold J.D., Thomas S.A., Valett H.M. and Mulholland P.J., 2009. Nutrient uptake and mineralization during leaf decay in streams - a model simulation. Int. Rev. Hydrobiol., 94, 371-390. 